2014

\title{
Modeling Atmosphere Composition And Determining Explosibility In A Sealed Coal Mine Volume
}

Jianwei Cheng

Yi Luo

Follow this and additional works at: https://researchrepository.wvu.edu/faculty_publications

\section{Digital Commons Citation}

Cheng, Jianwei and Luo, Yi, "Modeling Atmosphere Composition And Determining Explosibility In A Sealed Coal Mine Volume" (2014). Faculty Scholarship. 17.

https://researchrepository.wvu.edu/faculty_publications/17 


\author{
MODELING ATMOSPHERE COMPOSITION AND DETERMINING EXPLOSIBILITY \\ IN A SEALED COAL MINE VOLUME
}

\title{
MODELOWANIE SKLADU POWIETRZA I OKREŚLANIE NIEBEZPIECZEŃSTWA WYBUCHU W ZAMKNIĘTEJ PRZESTRZENI W OBRĘBIE KOPALNI WĘGLA
}

\begin{abstract}
Explosions originated from or around the sealed areas in underground coal mines present a serious safety threat. The explosibility of the mine atmosphere depends on the composition of oxygen, combustible and inert gases. In additional, the composition in the inaccessible sealed areas change with time under various factors, such as gases emissions, air leakage, inert gases injected, etc. In order to improve mine safety, in this paper, a mathematical model based on the control volume approach to simulate the atmosphere compositions is developed, and the expanded Coward explosibility triangle diagram is used to assess the mine gas explosion risk. A computer program is developed to carry out the required computations and to display the results. In addition, the USBM explosibility diagram is also included in the program to serve as a double check.
\end{abstract}

Keywords: mine sealed atmosphere; mine gas explosibility; simulation model; dynamic atmosphere changes

Wybuchy powstające wewnątrz lub wokół zamkniętych (odizolowanych) regionów w podziemnych kopalniach węgla stanowią poważne zagrożenie. Możliwość wystąpienia wybuchu powietrza kopalnianego uzależniona jest od proporcji zawartego w nim tlenu, gazów palnych i gazów obojętnych. Ponadto, skład atmosfery wewnątrz zamkniętych odizolowanych przestrzeni ulega zmianom w czasie pod wpływem różnorakich czynników: wydzielanie gazów, przecieki powietrza, doprowadzanie gazów obojętnych. Dla poprawy bezpieczeństwa pracy w kopalni opracowano model matematyczny bazujący na metodzie objętości kontrolnej dla symulacji składu powietrza. Rozszerzony wykres Cowarda wskazujący skłonność do wybuchu wykorzystany został do oszacowania ryzyka wystąpienia wybuchu gazów kopalnianych. Opracowano program komputerowy który wykonuje niezbędne obliczenia i wyświetla wyniki. Ponadto, dla dodatkowego potwierdzenia wyników wykorzystano wykres USBM obrazujący niebezpieczeństwo wybuchu.

Slowa kluczowe: powietrze w odizolowanej części kopalni, niebezpieczeństwo wybuchu gazów kopalniach, model symulacyjny, dynamiczne zmiany składu powietrza

\footnotetext{
* COllege of SAFETy ENGINEERING, ChINA UNIVERSITY OF MINING AND TECHNOLOGy, XUZHOU, JIANGSU, 221116, P.R. CHINA.

** DEPARTMENT OF MINING ENGINEERING, WEST VIRGINIA UNIVERSITY, MORGANTWON, WV, 26506, U.S.A.

1 CORRESPONDING AUTHOR: E-mail address: jchengwvu@gmail.com
} 


\section{Introduction}

Underground coal mines normally choose to seal old mined areas so that ventilation to these areas is no longer needed. Sealing is also a common way to extinguish large mine fires. In normal condition, once a mined area is sealed the methane concentration would increase (Szlazak \& Kubaczka, 2012). The atmosphere in the sealed area will go through a critical period in which methane concentration would be between the lower and upper explosive limits. Injection of inert gas $\left(\mathrm{N}_{2}\right.$ or $\left.\mathrm{CO}_{2}\right)$ is often employed to shorten this critical period. For effectively managing the atmosphere in the sealed areas, it is very important to know its gas composition, changing patterns and explosibility in advance. In other words, the explosion or fire risk assessment should be considered in an integrated manner (Cioca \& Moraru, 2012). It should be noted that the change of gas composition in a sealed volume is controlled by many independent variables such as inflows of methane and other combustible gases, air leakage in and out through the mine seals, inert gases injected into the sealed volume, and change in atmospheric pressure. A simulation tool to determine the gas composition and subsequently its explosibility considering all these independent variables would be very useful tool for managing the sealed mine atmosphere.

A number of methods have been proposed for assessing the explosibility of the air-gas mixture. Kukuczka analyzed compositions of the coal mine gas and created a model to determine the explosibility through a mathematical transformation to convert intricate combustible contents into a single gas (Kukuczka, 1982). Jacobs and Porter (1998) proposed their algorithms to generate a control chat depicting the changes in percent of combustibles and the lower and upper explosive limits of the current atmosphere. It also provided a prediction option for the user to look into the potential changes in the atmosphere over a period of time. The USBM explosibility diagram is a method widely used in the U.S. mining industry (Ray et al., 2004). This method uses the effective combustibles (converted from the methane, hydrogen, and carbon monoxide) and the effective inert (converted from the carbon dioxide and nitrogen) in the atmosphere to assess the explosibility of the mine atmosphere.

This paper presents a mathematical model based on the control volume approach to simulate the time-dependent atmosphere composition in a sealed mine area. The expanded Coward explosive triangle method to determine the explosibility of the mine atmosphere considering all combustible mine gases is also presented. The program to facilitate the application of the gas composition simulation model and to determine the explosibility is demonstrated.

\section{Time-dependent Composition change model for sealed atmosphere}

\subsection{The Control Volume Approach}

According to the law of mass conservation, the mass may be neither created nor destroyed. With respect to a constant sealed volume, the law of conservation of mass can be simply described as:

\begin{tabular}{|c|c|c|c|c|}
\hline $\begin{array}{l}\text { Rate of mass } \\
\text { efflux from } \\
\text { sealed volume }\end{array}$ & - & $\begin{array}{l}\text { Rate of mass } \\
\text { efflux into } \\
\text { sealed volume }\end{array}$ & + & $\begin{array}{l}\text { Rate of accumulation } \\
\text { of mass within } \\
\text { sealed volume }\end{array}$ \\
\hline
\end{tabular}




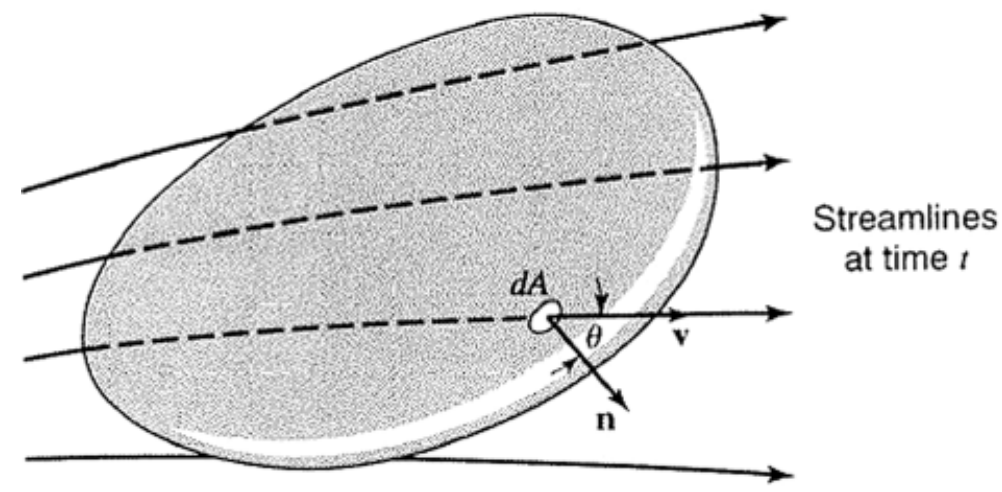

Fig. 1. Fluid flow through a control volume

Considering a general control volume ${ }^{1}$ located in a fluid flow field as shown in Figure 1, for the small element of area $d A$ on the control surface, assuming the velocity vector is $\mathbf{v}$ and $\theta$ is the angle between the velocity vector and the outward directed unit normal vector, $\mathbf{n}$ to $d A$. From vector algebra, the rate of mass efflux can be rewritten as (Welty et al., 2001:

$$
\rho(\mathbf{v} \cdot \mathbf{n}) d A=\rho v d A|\mathbf{v}||\mathbf{n}| \cos \theta
$$

Physically, this dot product represents the amount of mass flowing through a unit crosssectional area per unit time. If integrating this quantity over the entire control surface, the net outward flow of mass across the control surface, or the net mass efflux from the control volume can be expressed as:

$$
\iint_{C . S .} \rho(\mathbf{v} \cdot \mathbf{n}) d A
$$

On the other hand, the rate of accumulation of mass within the control volume may be expressed as:

$$
\frac{\partial}{\partial t} \iiint_{C . V} \rho d V
$$

The integral expression for the mass balance over a general control volume becomes:

$$
\iint_{C . S .} \rho(\mathbf{v} \cdot \mathbf{n}) d A+\frac{\partial}{\partial t} \iiint_{C . V} \rho d V=0
$$

\footnotetext{
${ }^{1}$ A control volume: A definite volume specified in space. Matter in a control volume can change with time as matter enters and leaves its control surface.
} 


\subsection{Step-wise dynamic simulation model}

The "Gob Assistant Program" (Foster-Miller, 1988) may have been the first effort to understand the sealed atmosphere quantitatively and to calculate leakage quantity in and out. Later, Zipf and Mohamed (2010) carry on the ideas and develop their model that can handle up to four different gas species, which are $\mathrm{Q}_{2}, \mathrm{~N}_{2}, \mathrm{CO}_{2}$ and $\mathrm{CH}_{4}$. Such developed mathematical model is based on the approach using the rate of change method. However, the drawbacks are: a) the time rate of change is often expressed as a ratio between a change in one variable relative to a corresponding change in another with focusing one specific location. It is not sufficient to reflect the atmosphere's overall changing features; b) the leakge coefficient used fails to consider the effects of the number of mine seals used at the same time. However, with the help of the Atkinson's question, a more clear relationship equation can be derived; c) The actual barometric pressure data should be summarized and included; d) Due to the complicated gas compositions in the sealed area, more gas species should be considered.

A mathematical model is developed to simulate the composition change in a sealed mine area. Common combustible gases emitting from surround strata or generating from coal mine fires or explosions. Generally, three general categories of gases make up the atmosphere mixture in a sealed mine area. They are: (1) atmospheric gases, (2) products of low temperature oxidation, combustion or explosion (Timko and Derick, 2006), and (3) the gas emitted from the coal seam such as $\mathrm{CH}_{4}$ and $\mathrm{CO}_{2}$. The byproduct gases of gas explosion and coal oxidation in the sealed volume are $\mathrm{CO}_{2}, \mathrm{CO}$, and $\mathrm{C}_{\mathrm{x}} \mathrm{H}_{\mathrm{y}}$ as shown in the following chemical reaction equations.

Coal oxidation:

$$
a \mathrm{Coal}+b \mathrm{O}_{2}=c \mathrm{CO}+d \mathrm{CO}_{2}+e \mathrm{H}_{2} \mathrm{O}+f \mathrm{C}_{x} \mathrm{H}_{y}
$$

In Eq. 2, $a, b, c, d, e$ and $f$ are stoichiometric coefficients. Field experiences show $\mathrm{C}_{\mathrm{x}} \mathrm{H}_{\mathrm{y}}$ is generally the alkane $\left(\mathrm{C}_{n} \mathrm{H}_{2 n+2}\right)$, alkene $\left(\mathrm{C}_{n} \mathrm{H}_{2 n}\right)$ or alkyne $\left(\mathrm{C}_{n} \mathrm{H}_{2 n-2}\right)$ series of hydrocarbon gases. In coal mine fires or explosions, acetylene $\left(\mathrm{C}_{2} \mathrm{H}_{2}\right)$, ethylene $\left(\mathrm{C}_{2} \mathrm{H}_{4}\right)$ and ethane $\left(\mathrm{C}_{2} \mathrm{H}_{6}\right)$ are often found in the underground air. Hence, the scales of the new model is capable of nine gas species, which are $\mathrm{CH}_{4}, \mathrm{CO}, \mathrm{N}_{2}, \mathrm{C}_{2} \mathrm{H}_{2}, \mathrm{C}_{2} \mathrm{H}_{4}, \mathrm{C}_{2} \mathrm{H}_{6}, \mathrm{CO}_{2}, \mathrm{H}_{2}$ and $\mathrm{O}_{2}$. Figure 2 shows the airflow exchanges between the sealed volume and its surroundings. In the sealed volume $(V)$, the atmosphere is consisted of the nine gases mentioned above. The volume occupied by each gas is denoted by subscripts with corresponding chemical formula. The total pressure in the sealed volume $\left(P_{t}\right)$ is the sum of the partial pressures of the individual gases. The barometric pressure outside the sealed volume is shown as $P_{v}$. Apparently, if $P_{t}<P_{v}$, the outside air flows through the mine seals into the sealed volume and this process is called air-inflowing. Conversely, if $P_{t}>P_{\mathrm{v}}$, air in the sealed volume flows out and it is called gas-outflowing. In addition, this model also considers the inflow of combustible gas, mainly $\mathrm{CH}_{4}$ from surrounding strata to the sealed volume. The effects of injecting inert gas into the sealed volume to prevent potential gas explosion can be also simulated.

Therefore, the concentration and partial pressure of each gas in the sealed volume would change with time and the changes are controlled by the inflows and outflows as well as by the atmospheric pressure.

Unlike the previous mentioned models, the new mathematical model is derived based on the control volume approach but also follows the law of mass conservation and the ideal gas law. 


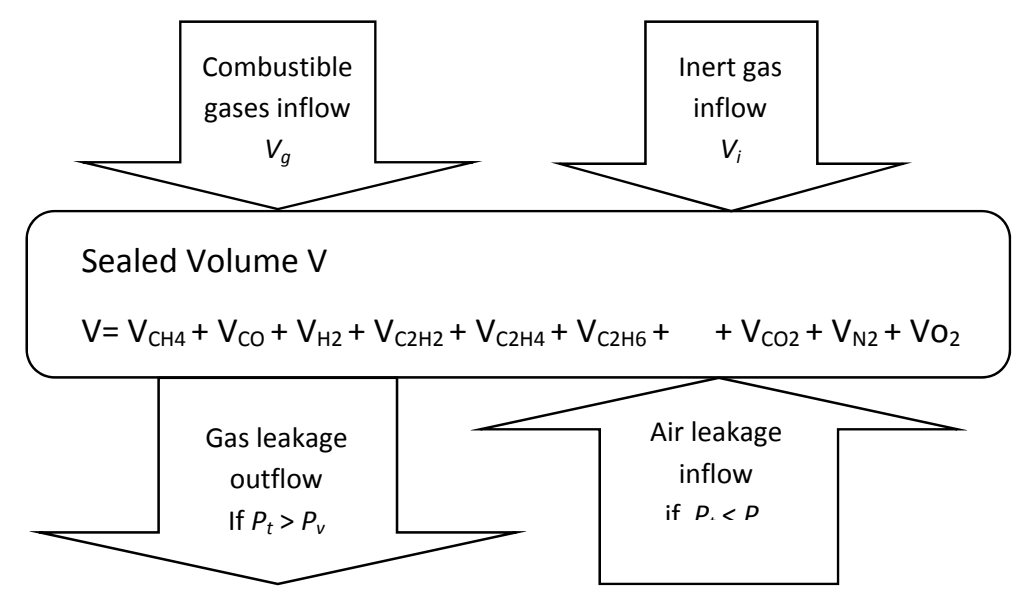

Fig. 2. Volume of the sealed atmosphere and its leakage depending on the differential pressure

(After Zipf \& Mohamed, 2010)

The model can be considered as a fine and improved model, and still following some assumptions made in pervious works:

1) The volume of the sealed mine area $(V)$ is constant.

2) The gas composition throughout the sealed volume is homogeneous.

3) Any added gases, such as emitted combustible gases, injected inert gas or the air leaked into the sealed volume will be mixed instantaneously.

4) The gas composition of the outgassing flow is identical to that of the sealed atmosphere.

5) The inert $A_{r}$ concentration in the sealed volume is negligible and assumed zero.

6) The temperature in the sealed area remains to be constant.

7) The mass and the pressure can be connected with using the ideal gas law, for each gas in the sealed volume, the following equation is established:

$$
P V=m R_{g} T
$$

In this equation $P$ is the partial pressure of a given gas; $V$ is the sealed volume; $m$ is the total mass of the gas; $R_{g}$ is the specific gas constant; and $T$ is the absolute temperature.

When the total gas pressure in the sealed area is lower than the atmospheric pressure outside, $P_{t}(t)<P_{v}(t)$, it is a air-inflowing condition. The normal mine air flows into the sealed volume.

$$
\left\{\begin{array}{l}
-\dot{m}_{i}+\frac{d m_{i}}{d t}=0 \\
P_{i}(t) V=m R_{i} T \\
P_{t}(t)=\sum_{i=1}^{9} P_{i}(t) \\
Q_{L}=n \sqrt{\frac{P_{v}(t)-P_{t}(t)}{R}}
\end{array}\right.
$$


When the total gas pressure in the sealed area is higher than the atmospheric pressure outside, $P_{t}(t)>P_{v}(t)$, it is a gas-outflowing condition. The gases flow out of the sealed volume.

$$
\left\{\begin{array}{l}
\frac{m_{i}}{M(t)} \dot{m}_{\text {mix }}-\dot{m}_{i}+\frac{d m_{i}}{d t}=0 \\
P_{i}(t) V=m R_{i} T \\
P_{t}(t)=\sum_{i=1}^{9} P_{i}(t) \\
Q_{L}=\sqrt[n]{\frac{P_{t}(t)-P_{v}(t)}{R}} \\
M(t)=\sum_{i=1}^{9} m_{i} \\
\dot{m}_{\text {mix }}=\rho_{\text {mix }} Q_{L} \\
\rho_{\text {mix }}=\sum_{i=1}^{9} \frac{m_{i}}{M(t)} \rho_{i}
\end{array}\right.
$$

The variables and constants in equations are defined as follows: The subscript " $i$ " represents each of the nine gases in the sealed volume. They are listed as $i=1 \ldots 9$ for $\mathrm{CH}_{4}, \mathrm{~N}_{2}, \mathrm{O}_{2}, \mathrm{CO}, \mathrm{CO}_{2}$, $\mathrm{H}_{2}, \mathrm{C}_{2} \mathrm{H}_{2}, \mathrm{C}_{2} \mathrm{H}_{4}$ and $\mathrm{C}_{2} \mathrm{H}_{6}$, respectively. Term $m_{i}$ is the total mass of gas $i$ in the volume and is a function of time. Term $\dot{m}_{i}$ is the rate of mass change of gas $i$ in the volume. In an air-inflowing process, they are defined as:

$$
\begin{gathered}
\dot{m}_{1}=\rho_{1} Q_{\mathrm{CH}_{4}} \\
\dot{m}_{2}=0.75 \rho_{\text {air }} Q_{L}+\rho_{2} Q_{\mathrm{N}_{4}} \\
\dot{m}_{3}=0.25 \rho_{\text {air }} Q_{L} \\
\dot{m}_{4}=\dot{m}_{5}=\dot{m}_{6}=\dot{m}_{7}=\dot{m}_{8}=\dot{m}_{9}=0
\end{gathered}
$$

In the gas-outflowing process, they are defined as:

$$
\begin{gathered}
\dot{m}_{1}=\rho_{1} Q_{\mathrm{CH}_{4}} \\
\dot{m}_{2}=\rho_{2} Q_{\mathrm{N}_{2}} \\
\dot{m}_{3}=\dot{m}_{4}=\dot{m}_{5}=\dot{m}_{6}=\dot{m}_{7}=\dot{m}_{8}=\dot{m}_{9}=0
\end{gathered}
$$

Where $Q_{\mathrm{CH}_{4}}$ is the $\mathrm{CH}_{4}$ volumetric inflow rate and $Q_{\mathrm{N}_{2}}$ is the $\mathrm{N}_{2}$ volumetric inflow rate injected into the sealed volume. They are assumed to be $100 \%$ pure. $\rho_{\text {air }}$ is the air density.

$R_{i}$ - specific gas constant of gas $i$.

$\rho_{i}$ - density of gas $i$ at standard pressure and temperature.

$P_{i}$ - partial pressure of gas $i$ at a given time.

$M$ - total mass of the gases in the sealed volume at a given time. 
$P_{t}$ - total pressure or the sum of the partial pressures of all individual gases at a given time.

$P_{V}-$ barometric pressure outside of the sealed area. It could change significantly over time

$T$ - absolute temperature.

$V$ - volume of the sealed atmosphere.

$Q_{L}$ - volumetric leakage rate in or out of the sealed volume through the mine seals at a given time. It should be noted that $Q_{L}$ is significantly affected by the number of and the quality of the mine seals built around the sealed area. Generally, the more mine seals are used; the more leakage flow is induced since these seals act as a parallel system. On the other hand, the quality of mine seals is also important. Mine seals with poor quality offer less resistance to the leaking flow.

$n-$ number of the seals used.

$\dot{m}_{\text {mix }}$ - mass leakage rate from the sealed volume at a given time.

$\rho_{m i x}-$ density of gas mixture leaking through the mine seals at standard pressure and temperature at a given time.

\section{Expanded Explosibility Triangle}

In the original Coward explosive triangle (Coward 1952), There are only three combustible gases (i.e., $\mathrm{CH}_{4}, \mathrm{CO}$ and $\mathrm{H}_{2}$ ) considered. The explosibility of the mixture depends on the percent of the combustible gases and oxygen. Figure 3 shows the $\mathrm{CO}$ explosive triangles. A total of four zones can be found, which are non-explosive zone, not-explosive zone, explosive zone and impossible mixture zone, respectively. However, the gas- mixture can be changed from one zone to the other once boundary conditions change.

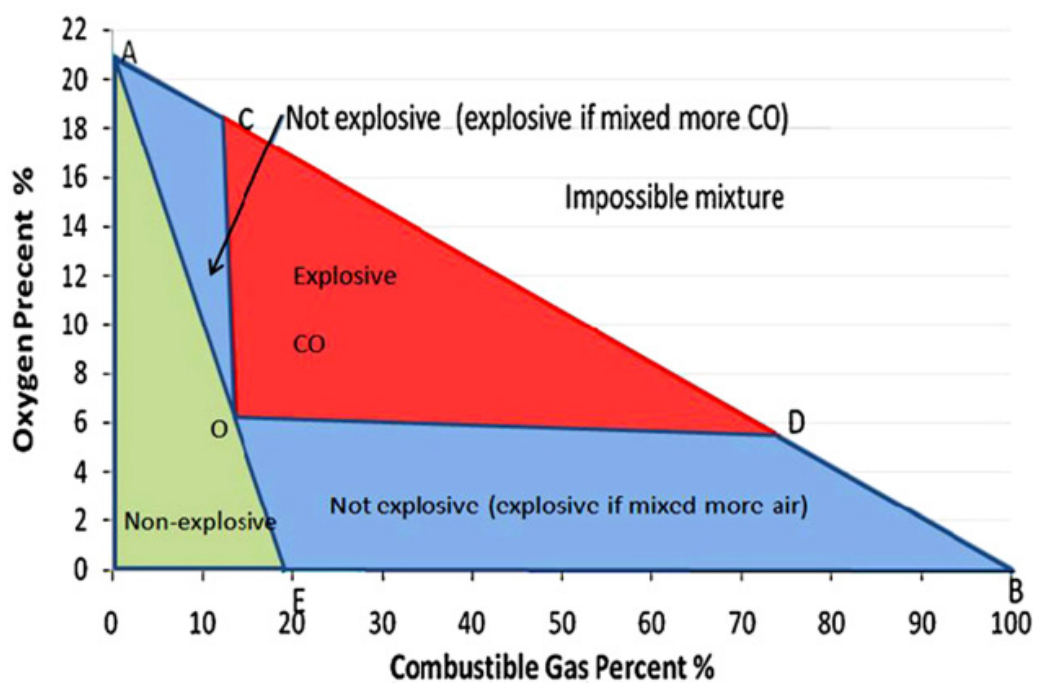

Fig. 3. CO explosive triangle 
Like discussed, various hydrocarbon gases may exist in the sealed volume and their concentration may be even higher than those of $\mathrm{CO}$ and $\mathrm{H}_{2}$. Hence, three more hydrocarbon gases, acetylene $\left(\mathrm{C}_{2} \mathrm{H}_{2}\right)$, ethylene $\left(\mathrm{C}_{2} \mathrm{H}_{4}\right)$ and ethane $\left(\mathrm{C}_{2} \mathrm{H}_{6}\right)$, are added to the original Coward method so that the expanded explosibility triangle can be obtained. The flammability limits for the all combustible gases are also listed in Table 1.

TABLE 1

Vertices of explosive triangles (percentages)

\begin{tabular}{|c|c|c|c|c|c|}
\hline \multirow[b]{2}{*}{ Gas } & \multicolumn{2}{|c|}{ Flammable Limits } & \multicolumn{2}{|c|}{ Nose Limits } & \multirow{2}{*}{$\begin{array}{l}\text { Nitrogen to be added to make mixture } \\
\text { extinctive: ( } N+\mathbf{m}^{3} \text { of nitrogen per } \mathbf{m}^{3} \\
\text { of combustible gas) }\end{array}$} \\
\hline & Lower & Upper & Gas & Oxygen & \\
\hline Methane $\left(\mathrm{CH}_{4}\right)$ & 5.00 & 14.00 & 5.90 & 12.20 & 6.07 \\
\hline Hydrogen $\left(\mathrm{H}_{2}\right)$ & 4.00 & 74.20 & 4.30 & 5.10 & 4.13 \\
\hline Carbon monoxide (CO) & 12.50 & 74.20 & 13.8 & 6.10 & 16.59 \\
\hline Ethylene $\left(\mathrm{C}_{2} \mathrm{H}_{4}\right)$ & 2.75 & 28.60 & 2.89 & 6.06 & 15.60 \\
\hline Ethane $\left(\mathrm{C}_{2} \mathrm{H}_{6}\right)$ & 3.00 & 12.50 & 3.12 & 8.41 & 12.80 \\
\hline Acetylene $\left(\mathrm{C}_{2} \mathrm{H}_{2}\right)$ & 2.50 & 80.00 & 2.67 & 5.07 & 28.91 \\
\hline
\end{tabular}

For these three more combustible gases, the procedure to generate the resultant Coward triangle is described as follows (After McPherson, 1993):

Determine the total combustibles percentage. If the volume percentages of the three combustible gases are $C_{1}, C_{2} \ldots$ and $C_{6}$, respectively. The total combustibles percentage is:

$$
C_{T}=C_{1}+C_{2}+\ldots+C_{6}
$$

- Determine the gas flammability. The Le Chatelier's principle in the form of Equation 18 is used to determine upper, lower and nose flammability of mixed gases. To apply this equation for the lower explosibility limit of the mixture $\left(L_{m i x}\right)$, the lower limits of the three gases are substituted in the places of $L_{1}, L_{2}, \ldots$ and $L_{6}$. The same can be done for the upper and nose limits.

$$
\frac{P_{T}}{L_{m i x}}=\frac{P_{1}}{L_{1}}+\frac{P_{2}}{L_{2}}+\ldots+\frac{P_{6}}{L_{6}}
$$

- Determine the required excess nitrogen. An effective way to render an air-gas mixture into a non-explosive one is to inject an excessive volume of nitrogen $\left(N_{e x}\right)$ into the mixture as shown in Eq. 19. In this equation, $L_{n}$ is the nose flammability of the mixed gases, $N+$ is the volumes of excess nitrogen to be added in order to make flammable gases extinctive (Inert ratio). Table 1 also presents the excess nitrogen if the combustible content consisted of one gas only.

$$
N_{e x}=\frac{L_{n}}{P_{T}}\left\{N_{1}^{+} P_{1}+N_{2}^{+} P_{2}+\ldots+N_{6}^{+} P_{6}\right\}
$$

- Determine the oxygen percentage at the nose limit $\left(O_{n}\right)$.

$$
O_{n}=0.2093\left(100-N_{e x}-L_{n}\right)
$$


Using the data obtained from these equations, the explosibility triangle for the air-gas mixture can be constructed, and the state point (i.e., concentrations of oxygen and total combustible gases) can be plotted on the same diagram. The relative position between the explosibility triangle and the state point shows the explosibility status of the air-gas mixture at current state and the potential when condition changes.

In order to ensure the reliability of the judgments made using the expanded Coward explosibility triangle, the USBM explosibility diagram is used as a supplemental method to double check the results. The monitored atmospheric composition data in an underground coal mine fire event after the mine was sealed were used to demonstrate these two methods. In this case, a very large amount of nitrogen was used to inert the mine fire and to prevent the mine atmosphere from becoming explosive. Table 2 shows the raw data from the mine atmosphere monitoring system. Figure 4 shows the histories of state points of the mine atmosphere and the explosibility triangles using the expanded Coward method and USBM explosibility diagram method. It can be seen that the gas-mixture is explosive at beginning but the final state point (red point) was out of the explosibility triangle and could be considered as non-explosive at that time. In this case, the oxygen concentration and the nitrogen concentration play important roles for the determination of explosibility. In two separate time periods, the nitrogen concentration often was comparatively low while the oxygen concentration was comparatively high and the gas-mixture in the sealed mine was judged to be explosive.

In addition, the judgments by the two methods are also listed in the table 2 . The result from the expanded Coward method agrees with that from USBM method. However, it should be noted that there are two conflicting cases in the table. The explosibility is determined as explosive by the expanded Coward method but non-explosive by the USBM diagram but close to the boundary line of the explosibility triangle. The reason is that more combustible gases are included in the expand Coward triangle, thus, the explosive zone is larger than the USBM diagram.

TABLE 2

Composition data recorded during a real mine fire

\begin{tabular}{|c|c|c|c|c|c|c|c|c|c|c|c|c|}
\hline \multirow[b]{2}{*}{ Nu. } & \multirow[b]{2}{*}{$\begin{array}{c}\text { Time } \\
\text { (hours) }\end{array}$} & \multirow[b]{2}{*}{$\begin{array}{l}\mathbf{O}_{2} \\
\%\end{array}$} & \multirow[b]{2}{*}{$\begin{array}{l}\mathbf{N}_{2} \\
\%\end{array}$} & \multirow[b]{2}{*}{$\underset{\%}{\mathrm{CO}_{2}}$} & \multirow[b]{2}{*}{$\begin{array}{c}\mathrm{CH}_{4} \\
\%\end{array}$} & \multirow[b]{2}{*}{$\begin{array}{c}\text { CO } \\
\text { ppm }\end{array}$} & \multirow[b]{2}{*}{$\begin{array}{c}\mathbf{H}_{2} \\
\mathbf{p p m}\end{array}$} & \multirow[b]{2}{*}{$\begin{array}{l}\mathrm{C}_{2} \mathrm{H}_{2} \\
\mathrm{ppm}\end{array}$} & \multirow[b]{2}{*}{$\begin{array}{l}\mathrm{C}_{2} \mathrm{H}_{4} \\
\mathrm{ppm}\end{array}$} & \multirow[b]{2}{*}{$\begin{array}{l}\mathrm{C}_{2} \mathrm{H}_{6} \\
\mathrm{ppm}\end{array}$} & \multicolumn{2}{|c|}{ Explosibility } \\
\hline & & & & & & & & & & & $\begin{array}{l}\text { By Expanded } \\
\text { Coward }\end{array}$ & $\begin{array}{c}\text { By USBM } \\
\text { Method }\end{array}$ \\
\hline 1 & 2 & 3 & 4 & 5 & 6 & 7 & 8 & 9 & 10 & 11 & 12 & 13 \\
\hline 1 & $\mathbf{0}$ & 16.96 & 75.03 & 1.67 & 4.98 & 2261 & 1741 & NDA & 62 & 500 & Yes & Yes \\
\hline 2 & 2 & 17.05 & 74.96 & 1.59 & 5.06 & 2162 & 1602 & NDA & 61 & 500 & Yes & Yes \\
\hline 3 & 4 & 17.77 & 70.54 & 0.56 & 10.07 & 1013 & 743 & NDA & 22 & 300 & Yes & Yes \\
\hline 4 & 6 & 17.90 & 70.48 & 0.49 & 10.11 & 864 & 642 & NDA & 19 & 300 & Yes & Yes \\
\hline 5 & 9 & 18.23 & 70.92 & 0.39 & 9.47 & 681 & 516 & NDA & 16 & 200 & Yes & Yes \\
\hline 6 & 11 & 18.47 & 71.19 & 0.31 & 9.07 & 408 & 344 & NDA & 11 & 200 & Yes & Yes \\
\hline 7 & 17 & 13.97 & 78.42 & 3.82 & 2.36 & 3175 & 1255 & NDA & 60 & 600 & No & No \\
\hline 8 & 23 & 14.26 & 77.75 & 3.46 & 3.09 & 3111 & 1121 & NDA & 47 & 800 & No & No \\
\hline 9 & 29 & 14.44 & 77.14 & 3.16 & 3.70 & 4329 & 1047 & NDA & 43 & 900 & No & No \\
\hline 10 & 35 & 13.96 & 76.64 & 3.26 & 4.53 & 4695 & 1114 & NDA & 45 & 1000 & No & No \\
\hline 11 & 39 & 13.90 & 76.57 & 3.25 & 4.68 & 4683 & 1075 & NDA & 47 & 1000 & Yes & No \\
\hline 12 & 41 & 13.71 & 76.48 & 3.37 & 4.84 & 4603 & 1044 & NDA & 44 & 1100 & Yes & No \\
\hline 13 & 45 & 17.67 & 71.35 & 0.70 & 9.30 & 741 & 218 & NDA & 9 & 300 & Yes & Yes \\
\hline
\end{tabular}




\begin{tabular}{|c|c|c|c|c|c|c|c|c|c|c|c|c|}
\hline $\mathbf{1}$ & $\mathbf{2}$ & $\mathbf{3}$ & $\mathbf{4}$ & $\mathbf{5}$ & $\mathbf{6}$ & $\mathbf{7}$ & $\mathbf{8}$ & $\mathbf{9}$ & $\mathbf{1 0}$ & $\mathbf{1 1}$ & $\mathbf{1 2}$ & $\mathbf{1 3}$ \\
\hline $\mathbf{1 4}$ & $\mathbf{4 9}$ & 18.59 & 72.32 & 0.38 & 7.78 & 445 & 117 & NDA & 4 & 200 & Yes & Yes \\
\hline $\mathbf{1 5}$ & $\mathbf{5 7}$ & 18.81 & 72.10 & 0.24 & 7.92 & 259 & 63 & NDA & NDA & 300 & Yes & Yes \\
\hline $\mathbf{1 6}$ & $\mathbf{6 1}$ & 18.87 & 71.89 & 0.19 & 8.12 & 199 & 50 & NDA & NDA & 300 & Yes & Yes \\
\hline $\mathbf{1 7}$ & $\mathbf{6 5}$ & 18.92 & 71.79 & 0.17 & 8.21 & 139 & 45 & NDA & NDA & 400 & Yes & Yes \\
\hline $\mathbf{1 8}$ & $\mathbf{7 1}$ & 18.82 & 71.47 & 0.16 & 8.63 & 145 & 53 & NDA & NDA & 300 & Yes & Yes \\
\hline $\mathbf{1 9}$ & $\mathbf{7 9}$ & 12.19 & 78.08 & 5.33 & 2.62 & 6697 & 1266 & NDA & 46 & 500 & No & No \\
\hline $\mathbf{2 0}$ & $\mathbf{8 1}$ & 12.27 & 78.00 & 5.28 & 2.69 & 6623 & 1163 & NDA & 44 & 600 & No & No \\
\hline $\mathbf{2 1}$ & $\mathbf{8 5}$ & 11.95 & 77.64 & 5.31 & 3.24 & 6761 & 1844 & NDA & 44 & 600 & No & No \\
\hline
\end{tabular}

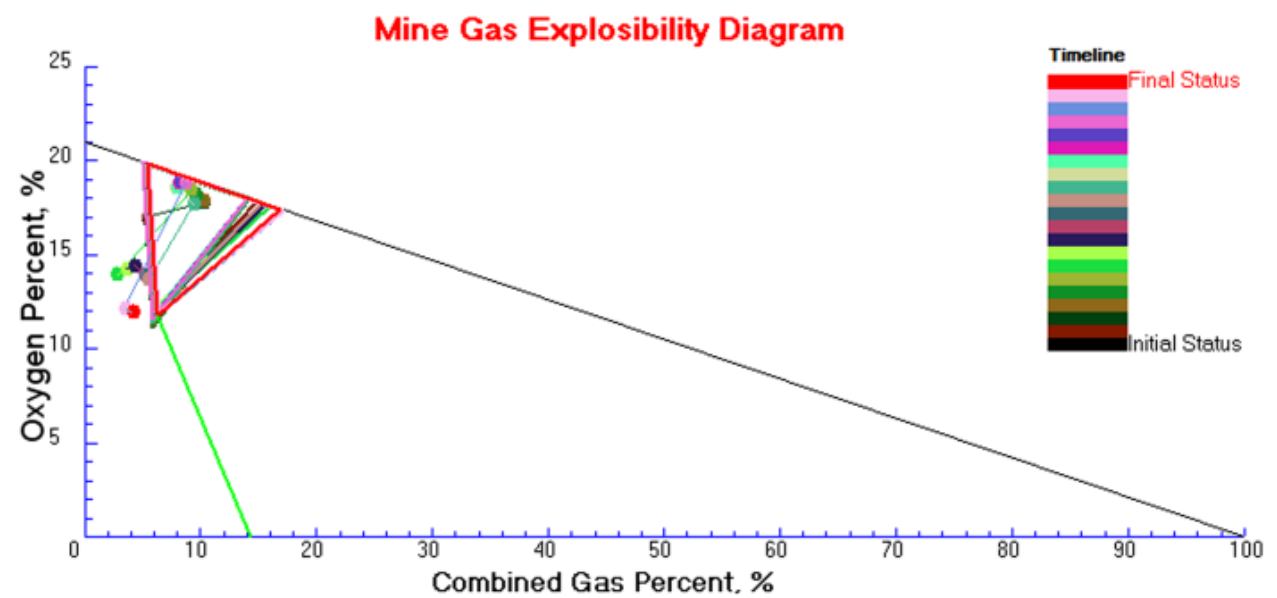

a) Results from expanded Coward explosibility triangle

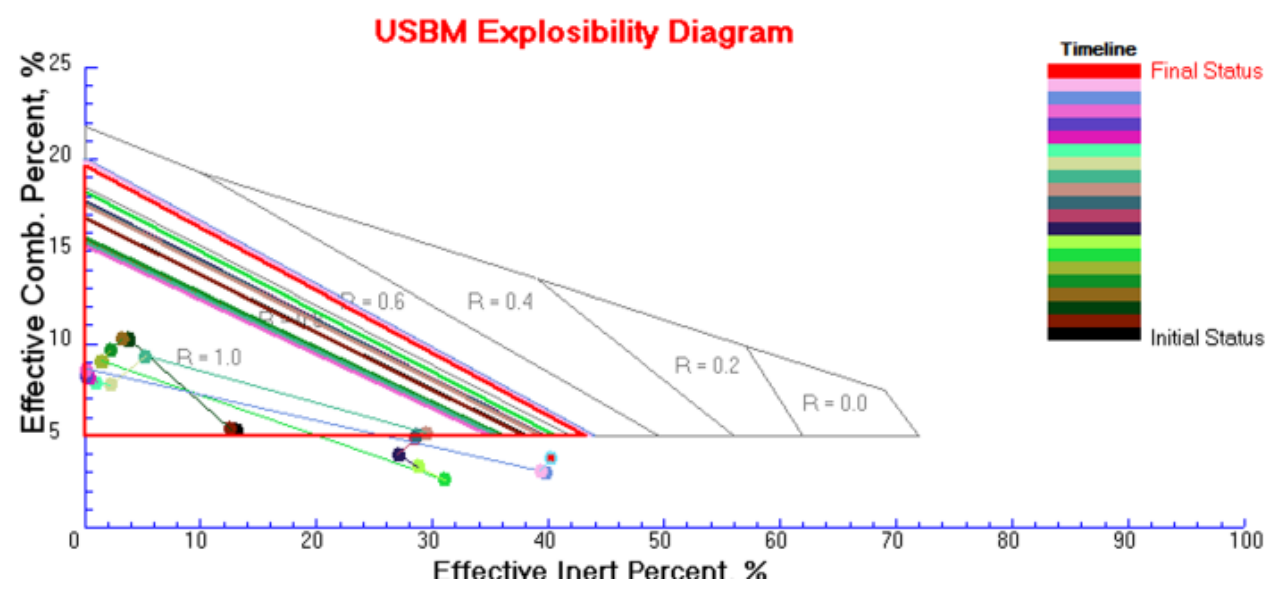

b) Results from USBM explosibility diagram

Fig. 4. Determining mine atmospheric explosibility using two methods for a real sealed mine fire 


\section{Program development}

An integrated Visual Basic program has been developed to implement both the mine atmosphere composition model and tracking the explosibility based on the expanded Coward triangle method. In the program, the main input data are the volume of and the initial condition in the sealed volume, the $\mathrm{CH}_{4}$ inflow rate and $\mathrm{N}_{2}$ injection rate, and barometric pressure, duration of simulation. The program automatically determines the time step length based on the specified simulation duration and performs the required computation at each of the time steps. At a given time, the program will calculate new partial pressure as well as the volumetric percentage for each gas in the sealed volume at a given time. Using the volumetric concentrations of the inert and combustible gases in the sealed atmosphere, the explosibility triangle and the state point of the air-gas mixture are determined. The resulting explosibility triangle and the state point of the mine atmosphere will be graphically displayed. The program also allows the user to input air sample data over a time period so the actual development trend can be reviewed. By analyzing such trend, the user can gain a better understanding of the explosibility of the mine atmosphere in the sealed area as well as the consequences of any actions taken on the sealed area.

Figure 5 is the screenshot for this program. A single sample point of the concentrations of the mine atmosphere can be manually entered or a series of sample points can be copied into the program.

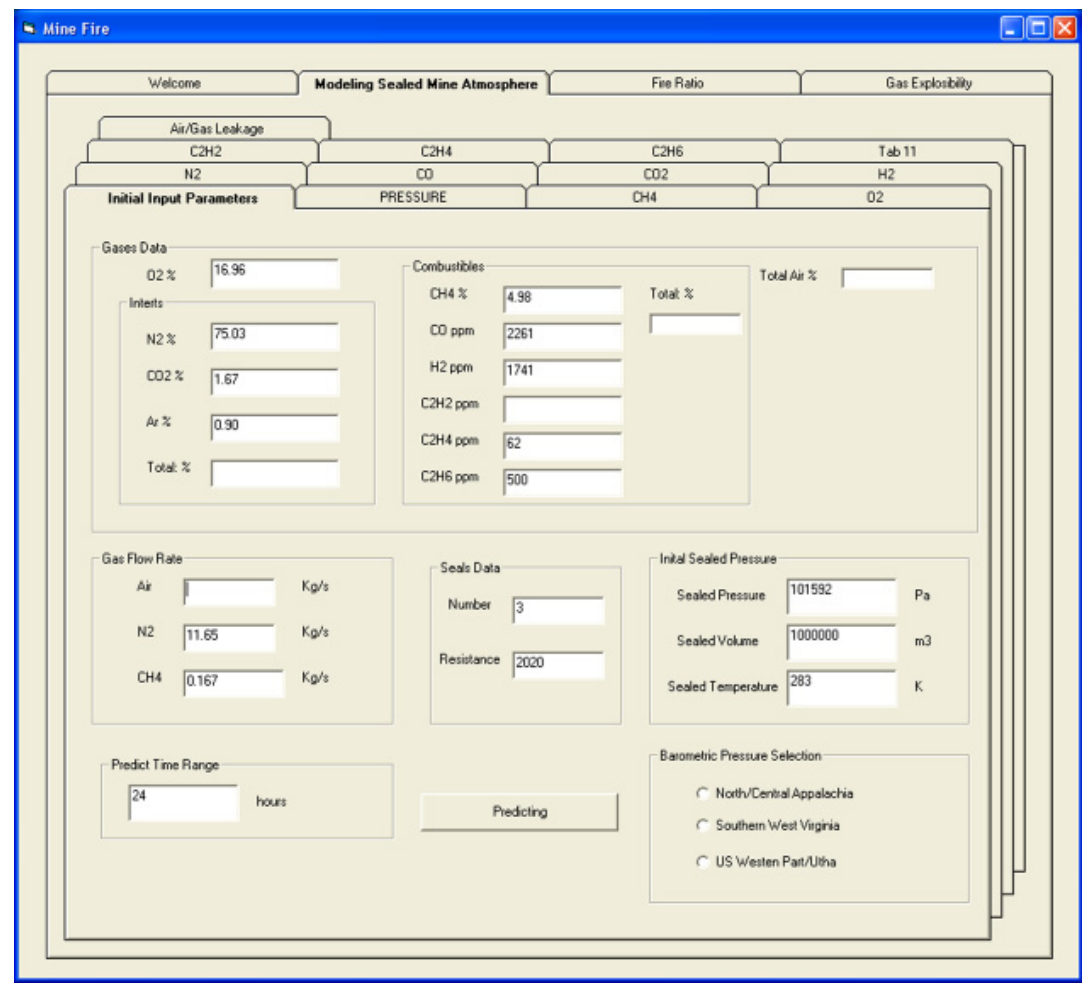

Fig. 5. Data input screen for the program 


\section{Cases Demonstrations}

\section{Case 1:}

In this case, an old coal mine area is simply sealed without any inertization. The simulation is performed to find how long the critical period would be. The parameters used in this case are the same as the ones published in Zipf and Mohamed's works. (Zipf \& Mohamed, 2010), as following statements.

The sealed volume is $1,000,000 \mathrm{~m}^{3}$ and three mine seals were used for the sealing. The initial conditions are: $\mathrm{CH}_{4}: 0 \% ; \mathrm{N}_{2}: 79 \%$ and $\mathrm{O}_{2}: 21 \%$ and the methane volumetric inflow rate in the sealed area is $0.25 \mathrm{~m}^{3} / \mathrm{s}$. In this case, the equivalent mass inflow rate is $0.167 \mathrm{Kg} / \mathrm{s}$. The design barometric pressure change is 6,000 Pa decreasing over 5 days. The mine temperature is assumed as $10^{\circ} \mathrm{C}$.

Figure 6 shows development trends of the gases in the sealed area. Due to continuous $\mathrm{CH}_{4}$ inflow from surrounding strata, all gas concentrations decrease except $\mathrm{CH}_{4}$, the increasing and high $\mathrm{CH}_{4}$ concentration would cause the sealed area inert itself. In additional, both the results calculated by the Zipf and Mohamed's model and the new mathematical model presented in this paper are shown in this figure. The curved lines without markers are the calculation results calculated by the Zipf and Mohamed's model, while the ones with markers indicate that they are calculated by the new mathematical model. It can be seen that the change rate of the Zipf and Mohamed's model for each gas species is a little bit faster than that of the new model, which means the sealed mine area becomes self-inertization is sooner based on their results. For an instance, Zipf and Mohamed present a $\mathrm{CH}_{4}$ concentration of $20 \%$ can be reached in about 9.3 days, but 11.2 days are needed with following the new one.

In order to check its explosibility, the expanded Coward triangles and the states point with a time step of 2.4 hours are determined and plotted in Figure 6 based on the mew model's cal-

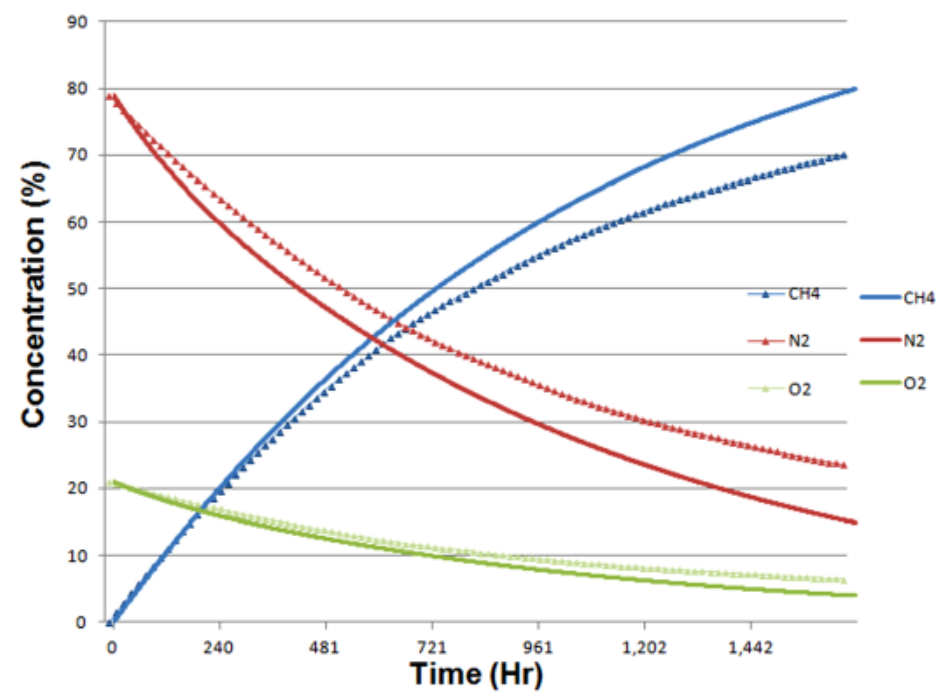

Fig. 6. $\mathrm{CH}_{4}, \mathrm{~N}_{2}$, and $\mathrm{O}_{2}$ change over time in the sealed volume 
culation results. The smallest explosibility triangle is that for the initial condition. As methane is continuously emitted into the sealed volume, the explosibility triangle expands. The red triangle is that at the end of simulation duration. Figure 7 also shows that the state point moves from left into the explosive zone on the second day after the area is sealed and moves out of it on the right on the seventh day. In other words, the critical time to manage the atmosphere in the sealed area lasted 6 days. The red dot is the final state point of the simulation.

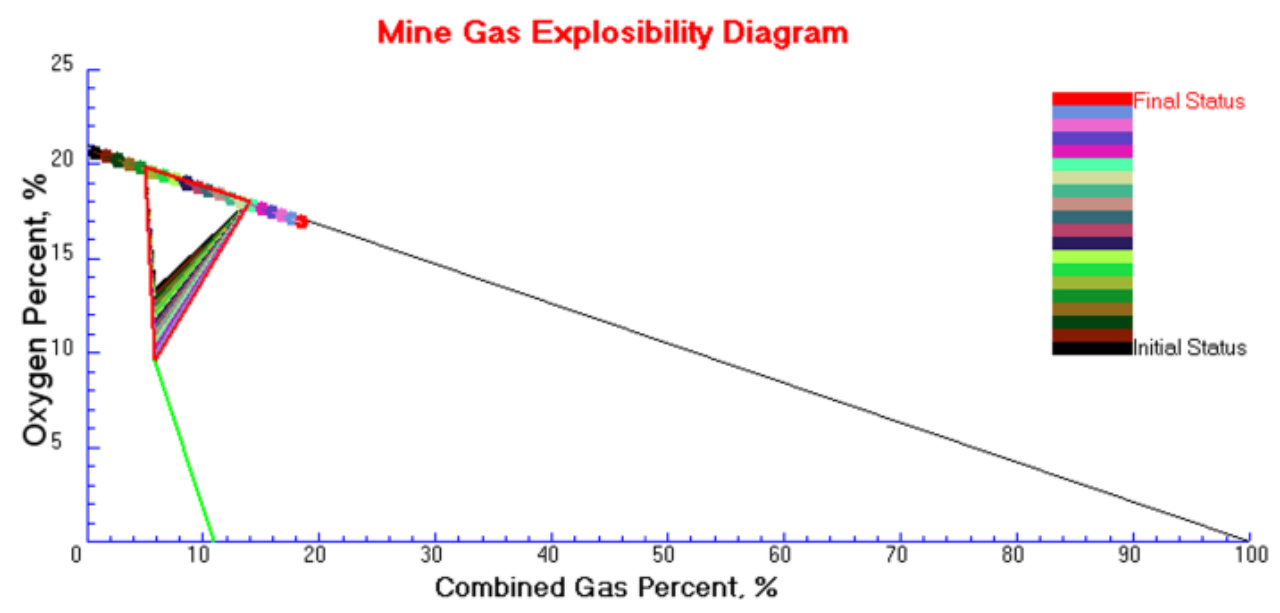

Fig. 7. Time-series plots of the explosibility triangles and the mixture points

\section{Case 2:}

In this case, inertization effort has been made to shorten the critical time period for managing the atmosphere in a sealed coal mine area. The developed model has been applied in a real coal mine. Due to the coal spontaneous combustion, elevated CO concentration event is found in a mine gob area. In order to control the suspicious "oxidation" event, mine operators carried out $\mathrm{CO}_{2} / \mathrm{N}_{2}$ injection to control the spontaneous combustion. The total volume of the gob area is $800,000 \mathrm{~m}^{3}$ and the environment temperature is $23^{\circ} \mathrm{C} . \mathrm{CO}_{2}$ was injected via the gob well at the rate of $40 \mathrm{~m}^{3} / \mathrm{min}$ while $\mathrm{N}_{2}$ was injected via the bleeder shaft at the rate of $45 \mathrm{~m}^{3} / \mathrm{min}$. Both the measured concentrations and the simulation model results (marked as "Sim." in Figure 8.) for all gas species in the gob area are plotted and compared with each other in the following Figure 8.

It can be seen from Figure 8 that the injection of $\mathrm{CO}_{2} / \mathrm{N}_{2}$ has strong impacts on the gas compositions in the sealed area. Simulation results show that $\mathrm{N}_{2}$ keeps high percentage concentration while $\mathrm{CH}_{4}$ and $\mathrm{CO}_{2}$ concentrations both have a certain amount of increasing, but other gases decrease. Comparing with field measurement data, the simulation results agree very well with them for each of gas species except $\mathrm{H}_{2}$ and $\mathrm{CO}$ since there are small differences (in terms of ppm) between the simulation results and the actual data. The reasons are a small scale spontaneous combustion may still happen in the underground, and the "piston effect" caused by the 


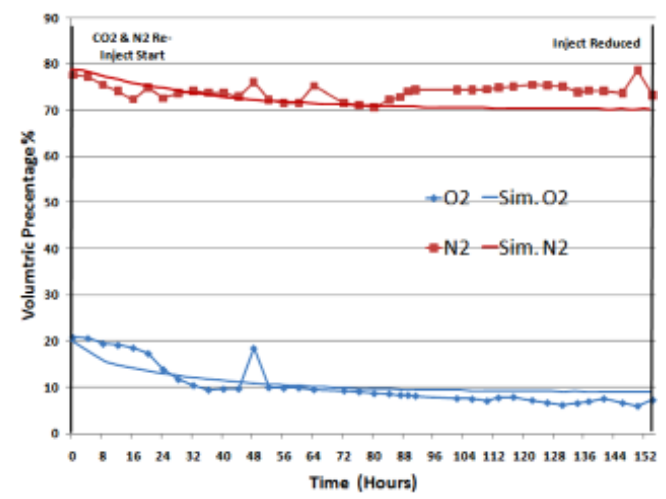

a) $\mathrm{N}_{2}$ and $\mathrm{O}_{2}$

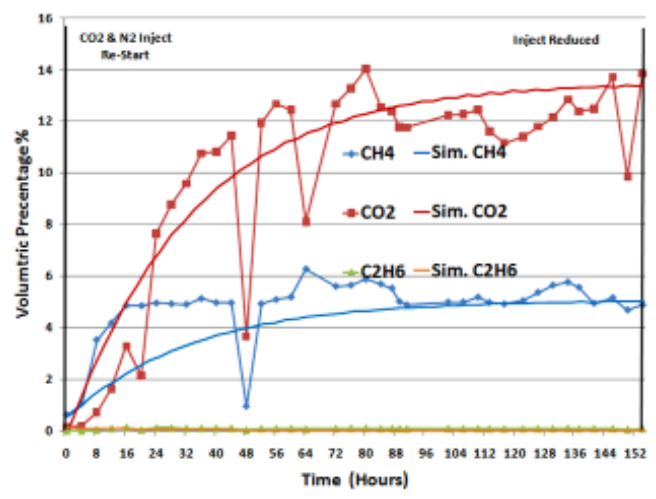

(b) $\mathrm{CH}_{4}, \mathrm{CO}_{2}$ and $\mathrm{C}_{2} \mathrm{H}_{6}$

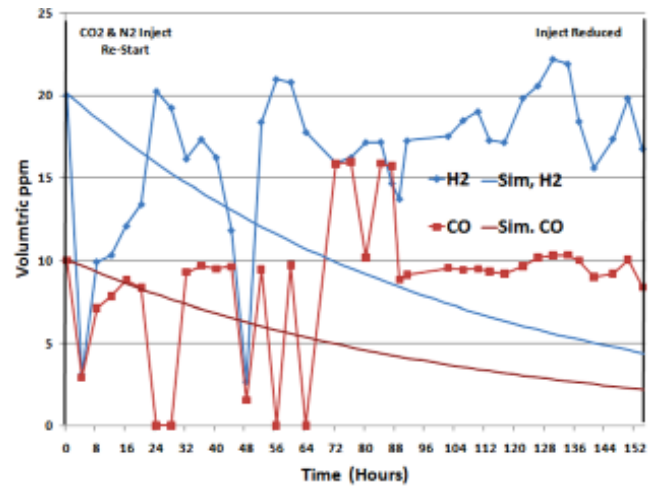

(c) $\mathrm{H}_{2}$ and $\mathrm{CO}$

Fig. 8. Comparisons of simulation results and field measurement data

injected inert gases results in the heterogeneous mixing process. However, it should be noted that the all simulation results can well show the change trend of each gas species over a time period. Then, the expanded Coward explosibility diagram to track the explosive trends is also plotted in Figure 9.

By observing Figure 9, the initial mine atmosphere state point locates near the left edge of the explosive triangle which means that the gas-mixture is explosive at the beginning. As the $\mathrm{CO}_{2} / \mathrm{N}_{2}$ continuous injection, the state point moves out of the explosive zone and comes into the not-explosive zone gradually, and the finial state points locates in the non-explosive zone. In other words, the gas-mixture becomes more and more safe. In order to validate the assessment using the expanded Coward method, the result is also checked again by the USBM explosibility diagram, and the results calculated by both of two methods agree very well with each other. 


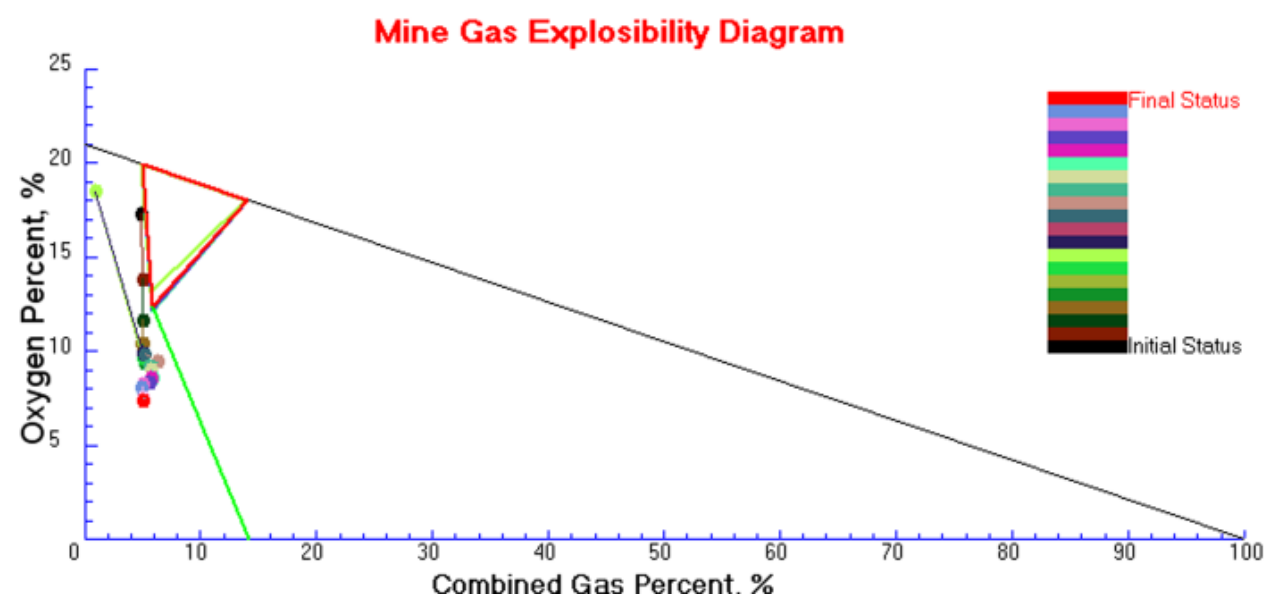

Fig. 9. Time-series plots of the explosibility triangles and the mixture points

\section{Conclusions}

A mathematical model to simulate the time-dependent composition change in the sealed volume has been developed based on the control volume approach. It well handles the atmosphere's overall changing features and could provide a reliable prediction with considering various influential factors It provides a useful tool for us to understand the behavior of the sealed volume. The expanded Coward method with considering more hydrocarbon gases is used to determine the explosibility of the sealed atmosphere. It should be noted that the expanded Coward method can be used to assess explosibility of mine air in any areas of an underground mine. A computer program to incorporate the atmosphere composition model and the expanded Coward method has been developed. It could serve as a good tool for managing the atmosphere in sealed mine areas.

\section{Acknowledgements}

This work is financially supported by grants from the Fundamental Research Funds for Central Universities (Grant No. 2013QNA01), the National Science Foundation of China (Grant No. 51304203) and the Natural Science Foundation of Jiangsu Province of China for Youths (Grant No. BK20130191); the authors are grateful for these supports.

\section{References}

Coward H.F., Jones G.W., 1952. Limits of Flammability of Gases and Vapors. U.S. Bureau of Mines, Bulletin 503, US Government Printing Office, $153 \mathrm{p}$.

Cioca I.-L., Moraru R.I., 2012. Explosion and/or Fire Risk Assessment Methodology: A Common Approach, Structured for Underground Coal Mine Environments. Archives of Mining Science, Vol. 57, No. 1, p. 53-60.

Foster-Miller, Inc., 1988. Improved ventilation of sealed mine gob. [In:] U.S. Bureau of Mines Contract Report J0308029. 
Jacobs M., Porter I., 1998. Rapid Generation of Control Charts for Analysis of Complex Gas Mixes in Crisis Situations. [In:] Proceedings of Coal 1998: Coal Operators' Conference. Wollongong: University of Wollongong \& the Australasian Institute of Mining and Metallurgy, p. 641-648.

Kukuczka M., 1982. A new method for determining explosibility of complex gas mixtures. Mechanizacja I Automatuzacja Gornictwa, 164 (11), p. 36-39.

McPherson M.J., 1993. Subsurface Ventilation and Environmental Engineering. Chapman \& Hall, London, United Kingdom.

Ray S.K., Singh R.P., Saha, N., Varma N.K., 2004. Assessing the status of sealed fire in underground coal mines. Journal of Scientific and Industrial Research, 63(7), p. 579-591.

Szlazak N., Kubaczka C., 2012. Impact of Coal Output Concentration on Methane Emission to Longwall Faces. Archives of Mining Science, Vol. 57, No. 1, p. 3-21.

Timko R.J., Derick R.L. 2006. Methods to determine the status of mine atmospheres - an overview. National Institute for Occupational Safety and Health Publications.

Welty J.R., Wicks C.E., Wilson R.E., Rorrer G., 2001. Fundamentals of Momentum, Heat, and Mass Transfer. New York, NY: John Wiley \& Sons, Inc. 780 p.

Zipf R.K., Mohamed K.M., 2010. Composition change model for sealed atmosphere in coal mines. Proc. 13th United States/North American Mine Ventilation Symposium, Ed. S. Hardcastle and D. McKinnon, Laurentian University, Sudbury, p. 493-500.

Received: 12 March 2013 